\section{Merck strengthens drug pipeline in rival takeover}

Pharmaceutical giant Merck will acquire its rival Schering-Plough in a US\$41billion deal announced on 9 March and unanimously approved by the boards of the New Jersey-based companies.

The move is seen as a way to protect the company's drug-development pipeline. The new company, which will be called Merck, would have 18 drugs in phase-III development, double what Merck had before. It also opens new markets for Merck: Schering-Plough earns $70 \%$ of its annual revenue outside the United States, including more than $\$ 2$ billion from emerging markets.

The deal is the latest in a series of drug-industry marriages: Pfizer paid $\$ 68$ billion in January to acquire Wyeth, and Roche recently boosted its offer to buy out Genentech to $\$ 46$ billion.

\section{Indonesia to sell carbon credits to conserve forests}

Indonesia has applied to join a World Bank programme intended to help developing nations fight deforestation by selling tradeable carbon credits.

International climate negotiators are working to allow developing nations the right to sell some carbon credits if they clamp down on deforestation, which is responsible for roughly $20 \%$ of global greenhouse-gas emissions. The World Bank's US\$300-million Forest Carbon Partnership Facility is designed to lay the groundwork for such an international agreement.

The programme already includes 25 countries, but Indonesia, the world's third-largest greenhouse-gas emitter, had remained on the sidelines until it applied in Feburary. The bank estimates that the country could earn between US\$400 million and $\$ 2$ billion selling credits for protecting forests.

\title{
Hawaiian waters yield corals with thirst for originality
}

Marine biologists have found seven new coral species, representing up to six new genera, in the deep waters of the Papahānaumokuākea Marine National Monument northwest of Hawaii.

The colourful bamboo corals, some of which were 4,000 years old, were discovered in November 2007 during a threeweek exploration of the conservation area, which was created under a proclamation by former US president George W. Bush in 2006.

The picture of this coral, from a seamount in water 1,750 metres deep, was taken by a submersible. The coral still lacks an official name. But members of biologist Les Watling's lab at the University of Hawaii at Manoa are calling it "Slurpisis". "It's built like a drinking straw, and 'isis' is the root name for the bamboo corals," explains Watling.

\section{Drug maker found liable despite FDA warning label}

Drug makers can be held liable for harm caused by their medicines, even if the drugs already carry federally approved warning labels, the US Supreme Court ruled on 4 March. The high court majority said that Diana Levine was entitled to a US\$6.7million award a state jury gave her, after she sued drug maker Wyeth of New Jersey.

A musician from Vermont, Levine had a Wyeth anti-nausea drug mistakenly injected into an artery, even though a label, approved by the US Food and Drug Administration (FDA), warned against such practice. Gangrene set in, and Levine's forearm was amputated.

The ruling means that FDA labels do not protect companies from liability in state courts, where they are often sued. It could affect many businesses that have sought increased federal regulation as a shield for liability.

For a longer version of this story, see: http://tinyurl.com/ckaubv.

\section{NIH-funded primate centre accused of mistreatment}

A Louisiana primate research centre came under federal investigation last week after an undercover probe by an animal-rights group alleged mistreatment of chimpanzees and monkeys.

The inquiry by the Humane Society of the United States also revealed that the National Institutes of Health $(\mathrm{NIH})$ contracted the facility, the New Iberia Research Center, part of the University of Louisiana at Lafayette, to breed infant chimps for research.
Although the NIH has had a moratorium since 1995 on breeding chimps for research, an NIH spokesman says this doesn't cover a US\$6-million contract that its National Institute of Allergy and Infectious Diseases (NIAID) made in 2002 with the centre to provide 4-12 infant chimps.

The US Department of Agriculture, which regulates primate facilities, announced an investigation on 5 March. The same day, legislators introduced a bill, the Great Ape Protection Act, seeking to ban all invasive research and testing on the estimated 1,000 research chimpanzees in the country.

Officials at the Centers for Disease Control and Prevention in Atlanta acknowledged that they received eight of the chimps for hepatitis $\mathrm{C}$ research under the NIAID contract.

\section{Mars orbiter plans to map out methane plumes}

NASA officials said on 3 March that the agency may pursue a 2016 launch of an orbital mission to scout for methane hotspots on Mars, in preparation for a 2018 lander mission that would perform astrobiological tasks.

The orbital mission, called the Mars Science Orbiter (MSO), would produce detailed maps of atmospheric methane plumes recently hinted at by Earth-based observations and by older evidence from the Mars Express orbiter, which is funded by the European Space Agency (ESA).

In an effort to pursue joint Mars missions, ESA and NASA are looking at ways to get the MSO and ExoMars, a $€ 1$.2-billion (US\$1.5-billion) rover also slated for a 2016 launch, on the same rocket. 